
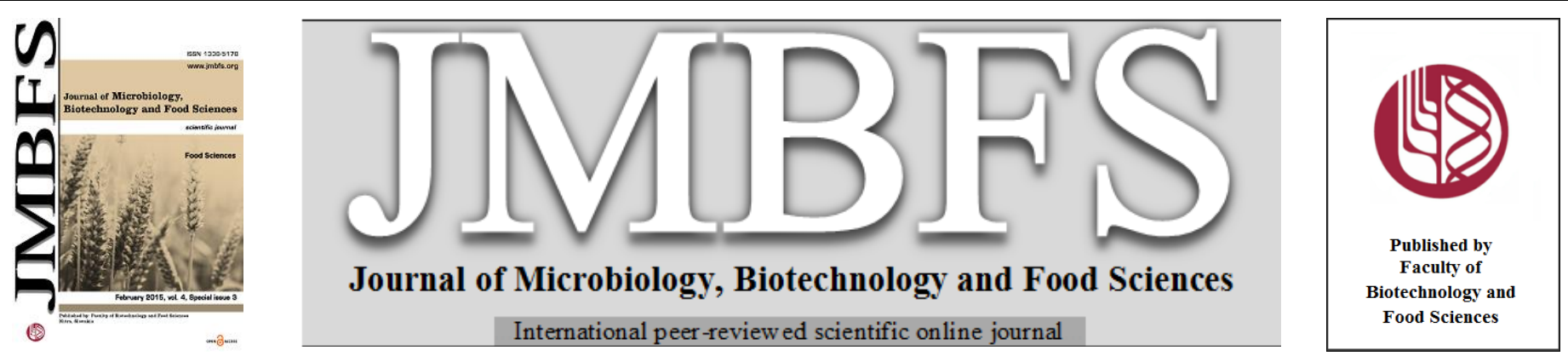

\title{
QUALITY ASSESSMENT OF EDIBLE TOMATO VARIETIES INTENDED FOR INDUSTRIAL PROCESSING
}

\author{
Andrea Mendelová ${ }^{* 1}$, Martina Fikselová ${ }^{2}$, Lubomír Mendel $^{3}$, Alena Andrejiová $^{4}$, Ján Mareček $^{1}$, Peter Czako ${ }^{1}$
}

Address(es): Ing. Andrea Mendelová, PhD.

${ }^{1}$ Slovak University of Agriculture in Nitra, Faculty of Biotechnology and Food Sciences, Department of Plant Processing and Storage, Tr. A. Hlinku 2, 94976 Nitra, Slovakia.

${ }^{2}$ Slovak University of Agriculture in Nitra, Faculty of Biotechnology and Food Sciences, Department of Food Hygiene and Safety, Tr. A. Hlinku 2, 94976 Nitra,

Slovakia.

${ }^{3}$ National Agricultural and Food Centre Research Institute of Plant Production, Brat islavská 122,921 01 Pieštany, Slovakia.

${ }^{4}$ Slovak University of Agriculture in Nitra, Horticult ure and Landscape Engineering Faculty, Department of Vegetable, Tr. A. Hlinku 2, 94976 Nitra, Slovakia.

*Corresponding author: andrea.mendelova@uniag.sk

doi: $10.15414 /$ jmbfs.2015.4.special3.114-117

\section{ARTICLE INFO}

Received 2.12.2014

Revised 6. 12. 2014

Accepted 7. 12. 2014

Published 2. 2. 2015

$\frac{\overline{\text { Regular article }}}{{ }_{\text {OPEN }}{ }_{\text {ACcESS }}}$

\begin{abstract}
Most of the global production of tomatoes is used for tomato products. The fruits to be processed are evaluated on the basis of important technological quality parameters, such as the content of dry matter and organic acids. Recently, among important qualitative characteristics of fruits has been included colorant content, especially lycopene. Aim of this study was to evaluate the quality of selected tomato varieties for industrial processing. Tested were varieties Uno Rosso, San Marzano 4, Brixol, Strombolino, UG. 8168, Diana and Nemarock cultivated in very hot and dry agro-climatic region. The dry mattercontent was determined by the gravimetric method, the content of organic acid by titration and the content of colorants spectrophotometrically. The dry matter content of the samples ranged from $4.65 \%$ (Nemarock) to 5.93\% (San Marzano 4). Content of organic acids ranged from 0.33\% (Nemarock) to 0.59\% (Strombolino), content of carotenoids in tomato samples ranged from $111.288 \mathrm{mg} .100 \mathrm{~g}^{-1} \mathrm{DM}$ (Nemarock) to $198.365 \mathrm{mg} .100 \mathrm{~g} \mathrm{~g}^{-1} \mathrm{DM}$ (San Marzano 4). Lycopene was present in the amount of $99.438 \mathrm{mg} .100 \mathrm{~g} \mathrm{~g}^{-1} \mathrm{DM}$ (Nemarock) to $192.687 \mathrm{mg} .100 \mathrm{~g}^{-1} \mathrm{DM}$ (San Marzano 4). In terms of treat ment the best properties showed San Marzano 4, which is characterized by high dry matter content, low organic acids and high content of colorants.
\end{abstract}

Keywords: Tomato, technological characteristics, dry matter, carotenoids, lycopene

\section{INTRODUCTION}

Tomato (Lycopersiconesculentum $\mathrm{L}$.) is being the second most important veget able crop worldwide (Agarwal and Rao, 2000; Agarwal, et al. 2001). Tomatoes are major components of daily meals in several countries. Due to their high consumption, tomatoes and tomato products represent a significant source of antioxidants in the human diet. Tomatoes are important dietary source of carotenoids, especially of lycopene and $\beta$-carotene. It is a major source of antioxidants contributing to the daily intake of a significant amount of these components. It is consumed as fresh or as processed products such as canned tomato, sauce, juice, ketchup, stews and soups (Lenucci et al., 2006).

The fruits of Lycopersicum esculentum owe their intense red color due to carotenoid pigments that are synthesized massively during the fruit ripening. Carotenoids are responsible for the final red color of the tomato $(\mathbf{Z e b}$ and Meh mood, 2004). Tomato antioxidants include carotenoids such as $\beta$-carotene, a precursor of vitamin A, and mainly lycopene, which is largely responsible for the red color of the fruit, vitamins such as ascorbic acid and tocopherols, and phenolic compounds such as flavonoids and hydroxycinnamic acid derivatives (Borguini and Torres, 2009; Clinton,1998; Kotíková et al., 2009; Kotíková et al., 2011; Moco et al., 2006; Vallverdú-Queralt et al., 2011).

The aim of this work was to analyze the quality of selected tomato varieties intended for industrial processing, based on the content of the dry matter, organic acids, total carotenoids and lycopene.

\section{MATERIAL AND METHODS}

In this work 7 edible varieties of tomato (Lycopersicum esculentum Mill.) were analyzed: Uno Rosso, San Marzano 4, Brix, Strombolino, UG. 8168, Nemarock and Diana. Uno Rosso, San Marzano 4, Brix, Strombolino, UG. 8168, Nemarock varieties are of It alian origin, variety Diana is Slovak origin. It is a determinate type varieties. The fruits are mainly intended for industrial processing.

Samples of tomatoes were cultivated in experimental fields of the SUA in Nitra. Area is situated in a very warm agro-climatic region, very dry sub-region. The average annual temperature is $10^{\circ} \mathrm{C}$, average annual rainfall is $584.5 \mathrm{~mm}$ and the average rainfall for the growing season is $287.5 \mathrm{~mm}$. In terms of soil characteristics, soil is a glue fluvisol, formed on alluvial sediments.

Fruits were harvested in a stage of technological maturity, when they are fully colored with character taste and aroma. The dry matter content was determined by gravimetric method. Homogenised samples were dried to constant weight at $105^{\circ} \mathrm{C}$ at WTC Binder laboratory oven.

Content of organic acids expressed as \% of citric acid was determined according to the Slovak Technical Standard (STN 560240-5). This method is based on the neutralization of the acids present with sodium hydroxide using a suitable indicat or. Total content of carotenoids was determined spectrophotometrically by the device Jenway UV-VIS according to the methodology given in the Slovak Technical Standard (STN 12136). Homogenised samples were extracted with acetone, then mixed with petroleum ether. Water was added for the separation of phases, and after the separation of the petroleum-ether-carotenoid phase the absorbance of a solution of carotenoids was measured at the wavelength of 445 $\mathrm{nm}$, the absorbance of lycopene was measured at the wavelength of $470 \mathrm{~nm}$. All analyzes were performed in triplicate.

Results of total carotenoids and lycopene content were processed by statistical program Statistica. The influence of variety on the content of carotenoids and lycopene was evaluated by one-way analysis of variance and Tukey HSD test.

\section{RESULTS AND DISCUSSION}

Evaluation of soluble dry matter content in tomato is in practice used as a basic indicat or for assessing the quality of fruits for processing. The dry matter content in tomatoes ranged from $4.65 \%$ in the variety Nemarock to $5.93 \%$ in San Marzano 4 (Table 1). 
$\underline{\text { Table } 1 \text { Assessment of selected quality indicators in edible tomatoes }}$

\begin{tabular}{lcccc}
\hline Variety & $\begin{array}{c}\text { Dry matter } \\
{[\%]}\end{array}$ & $\begin{array}{c}\text { Organic acids } \\
{[\mathbf{\%}]}\end{array}$ & $\begin{array}{c}\text { Carotenoids } \\
{\left[\begin{array}{c}\text { mg.100 } \\
\text { matter] }\end{array}\right.}\end{array}$ & $\begin{array}{c}\text { Lycopene } \\
{\left[\mathbf{m g . 1 0 0} \mathbf{g}^{-1} \text { fresh }\right.} \\
\text { matter] }\end{array}$ \\
\hline Uno Rosso & 4.66 & 0.36 & 9.04 & 8.76 \\
\hline San Marzano 4 & 5.93 & 0.37 & 11.76 & 11.43 \\
\hline Brixol & 5.91 & 0.40 & 9.86 & 9.68 \\
\hline Strombolino & 5.82 & 0.59 & 8.06 & 7.59 \\
\hline UG. 8168 & 5.09 & 0.50 & 7.09 & 6.66 \\
\hline Nemarock & 4.65 & 0.33 & 5.18 & 4.62 \\
\hline Diana & 5.63 & 0.38 & 8.44 & 8.22 \\
\hline
\end{tabular}

Anthon etal. (2011) reported that dry matter of tomato is consisted mostly of simple sugars, glucose and fructose. They investigated the dry matter content in the fruit of tomatoes intended for industrial processing, and they found that it varied from 4.6 to $5.4 \%$. In most varieties during storage before processing they state the increase in the dry matter content, to $5.6 \%$.

Majidi et al.(2011) investigated the dry matter content of tomatoes grown in Iran and they found that it is ranging from 5.2 to $5.99 \%$. They also observed some changes in the evaluation of the dynamics in the dry mat ter during storage in the cold store and in the st ock with a modified at mosphere, and found that the dry matter content during the 90-days storage in a cold store showed a slight increasing trend for the first 20 days and then decreased, in the stock with modified at mosphere dry matter decreased after 40 days of storage.

Content of organic acids ranged from $0.36 \%$ to $0.59 \%$. Diana variety was characterized by lower content of organic acids. In contrast, the highest content of organic acids showed Strombolino and UG. 8168.

Suárezet al. (2008) investigated the presence of organic acids in tomato fruits grown in Tenerife. Varieties Dorothy, Boludo, Dominique, Thomas and Dunkan showed the presence of oxalic acid, pyruvic acid, tartaric, malic, maleic, citric, fumaric and succinic acids.

Majidi et al. (2011) investigated the changes in organic acid content during storage in a cold warehouse in modified atmosphere and found a decrease in acidity especially when stored in ordinary cold storage.

Tomato fruits are in the stage of full maturity in characteristic intense red color and at the same time with solid consistency of fruits. The highest content of carotenoids was found in San Marzano 4, in which the mean value was 11.76 mg. $100 \mathrm{~g}^{-1}$ carotenoids. The lowest average carotenoid content $5.18 \mathrm{~g} \mathrm{mg.} 100 \mathrm{~g}^{-1}$ was determined in variety Nemarock. Content of carotenoids in the monitored variet ies decreased in the order: San Marzano $4>$ Brixol $>$ Uno Rosso > Diana > Strombolino > UG $8168>$ Nemarock.

Belitz et al. (2009) indicate that the total content of carotenoids in tomato fruit varies from 1.02 to $9.92 \mathrm{mg}$. $100 \mathrm{~g}^{-1}$. The highest content was recorded in varieties of Jubilee (9.92 mg. $\left.100 \mathrm{~g} \mathrm{~g}^{-1}\right)$ and Campbell $\left(7.28 \mathrm{mg} .100 \mathrm{~g}^{-1}\right)$. The lowest content of carotenoids was found in yellow variety Ace Yellow $(1.02 \mathrm{mg}$. $100 \mathrm{~g}^{-1}$ ). Ilahy et al. (2011) state the mean content of carotenoids in tomatoes grown in Italy from 0.51 to $9.49 \mathrm{mg} .100 \mathrm{~g}^{-1}$. Carli et al. (2011) monitored the content of carotenoids in 7 varieties of tomatoes and report their content from 3.63 to $17.5 \mathrm{mg}$. $100 \mathrm{~g}^{-1}$.

Carotenoid content after conversion to $100 \%$ dry matter was the highest at variety San Marzano 4 (198.365 mg. $\left.100 \mathrm{~g}^{-1}\right)$ and the lowest at Nemarock $(111.288 \mathrm{mg}$ $\left.100 \mathrm{~g}^{-1}\right)$. Content of carotenoids in the monitored varieties decreased in the order: San Marzano $4>$ Uno Rosso > Brixol > Diana > UG $8168>$ Strombolino > Nemarock.

Content of carotenoids observed Kotíková et al. (2009), who evaluated varieties Albertovské žluté, Bejbino F1, Cristina F1, Bonset F1, Dominato F1, Monika F1,

Orkado F1, Start SF1, Stupické polní rané, Tornádo F1 and Rougella F1. They found the average content of carotenoids in the amount of $66.5 \mathrm{mg} .100 \mathrm{~g}^{-1} \mathrm{DM}$ As varieties with higher contents of carotenoids authors indicate Bonset F1, Start S F1 a Cristina F1. Contrary, varieties Albertovskéžlté, Bejbino F1 and T ornádo F1 showed lower carotenoid yield.

By Tukey HSD test were shown differences in carotenoid content among varieties. Varieties est ablished five homogeneous groups, which were different in the content of carotenoids (Table 2).

Table 2 The mean content of carotenoids and lycopene (mg. $100 \mathrm{~g}^{-1}$ dry matter) in the fruit of the tomato and homogeneous groups based on Tukey's HSD test

\begin{tabular}{lccrr}
\hline Variety & \multicolumn{1}{l}{ Carotenoids } & \multicolumn{2}{l}{ Lycopene } \\
\hline Nemarock & 111.288 & a & 99.438 & a \\
\hline Strombolino & 138.552 & b & 130.358 & b \\
\hline UG. 8168 & 139.306 & b & 130.910 & b \\
\hline Diana & 149.870 & c & 145.940 & c \\
\hline Brixol & 166.881 & d & 163.753 & d \\
\hline Uno Rosso & 194.064 & e & 188.003 & e \\
\hline San Marzano 4 & 198.365 & e & 192.687 & f \\
\hline Values in the same column with different letters are significantly different $(\alpha<0.05)$
\end{tabular}

Statistically significant the lowest content of carotenoids was confirmed in variety Nemarock. The highest content of carotenoids was statistically significant in varieties Uno Rosso and San Marzano 4, which did not differ significantly in the content of the monit ored component. There was no significant difference between varieties Strombolino and UG. 8168.

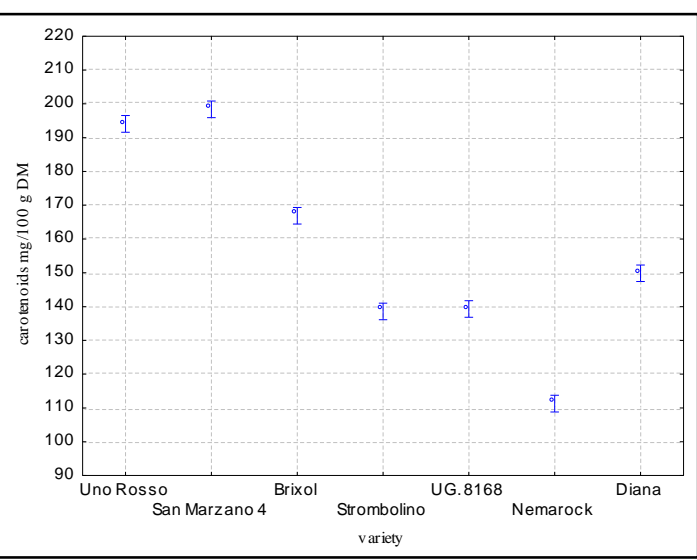

Figure 1 Comparison of averages of carotenoids (mg. $100 \mathrm{~g}^{-1}$ dry matter) in the tomato fruit 
Martínez-Valverde et al. (2002), Kuti and Konuru (2005) and GarcíaValverde etal. (2011) monitored content of total carotenoids, lycopene, $\beta$ carotene and found that their content is significantly affected by variety, growing location and degree of ripeness of the fruit.

As reported several authors, carotenoids are the subject of several studies which are focused on the prevention of cancers and eye diseases. Particular attention is paid to $\beta$-carotene, lycopene, lutein and zeaxanthin. Many studies have shown a strong correlation between consumption of tomatoes and their products and reducing the risk of some cancers, neurodegenerative diseases, degenerative diseases, cardiovascular disease and age-related macular degeneration (Giovannucci et al.,2002; Khachik et al., 2002; Muller et al., 2002; Sesso et al. 2003, 2004, Stahl and Sies 2005, Dorais, 2007).

Predominant carotenoid in tomatoes is lycopene. Srivastava and Srivastava (2012) reported that several epidemiological studies have shown a high biological potential of lycopene in the prevention of diseases and the incidence of many degenerative diseases. Lycopene showed strong antioxidant effects on animals and humans.

Bugianesi et al. (2004) state that epidemiological studies have shown that consumption of tomatoes and tomato products is associated with reduced incidence of chronic and degenerative diseases. This protective effect of tomatoes is due to the high content of various dietary components, carotenoids including lycopene and polyphenolic compounds.

In the monitored samples lycopene content ranged from $4.624\left(\mathrm{mg} .100 \mathrm{~g}^{-1}\right)$ in variety Nemarock to $11.426\left(\mathrm{mg} .100 \mathrm{~g}^{-1}\right)$ in San Marzano 4. Lycopene content in the studied varieties decreased in the order: San Marzano $4>$ Brixol $>$ Uno Rosso $>$ Diana > Strombolino > UG $8168>$ Nemarock. The average percentage of lycopene in the total carotenoids of the samples was $95.27 \%$.

Rajoria et al. (2010) reported that lycopene is nutrient which is represented in tomatoes up to $80 \%$ of pigments present. Sharma and Le Maguer (1996) determined in fresh fruit of tomato originating from Canada lycopene in the amount of $5.4 \mathrm{mg}$. $100 \mathrm{~g}^{-1}$

Martínez-Valverde et al. (2002) found in different commercial varieties of Spanish tomatoes, lycopene content at the amount of 1.8 to $6.5 \mathrm{mg}$. $100 \mathrm{~g} \mathrm{~g}^{-1}$ Toor et al. (2006) reported that lycopene in three commercial varieties (Excell, Tradiro, Flavourine) tomato ranged from 2.7 to $4.7 \mathrm{mg} .100 \mathrm{~g}^{-1}$.

Carli et al. (2011) monitored the content of lycopene and $\beta$-carotene in tomatoes They found lycopene content from 2.8 to $14.9 \mathrm{mg}$. $100 \mathrm{~g}^{-1}$ and $\beta$-carotene content of 0.12 to $0.949 \mathrm{mg} .100 \mathrm{~g}^{-1}$.

Walia et al. (2010) determined lycopene content in tomatoes from 2.74 to 6.55 $\mathrm{mg} .100 \mathrm{~g}^{-1}$. The difference in lycopene content in pulp and peel of the fruit was further investigated and it was discovered that the peel contains 3-5 times higher lycopene than the pulp.

Pohar et al. (2003) investigated the lycopene content in other vegetables. The highest content of lycopene was found in watermelons $\left(4.53 \mathrm{mg} .100 \mathrm{~g}^{-1}\right)$, in tomatoes $4.2 \mathrm{mg} .100 \mathrm{~g}^{-1}$ and grapefruit $3.91 \mathrm{mg} .100 \mathrm{~g}^{-1}$.

Lycopene content after conversion to $100 \%$ of dry matter was determined in our samples of tomatoes from $99.438 \mathrm{mg} .100 \mathrm{~g}^{-1} \mathrm{DM}$ to $192.687 \mathrm{mg} .100 \mathrm{~g}^{-1} \mathrm{DM}$

The highest content was in San Marzano 4 and the lowest in the sample of Nemarock. Testing by the Tukey HSD test were monitored differences in the content of lycopene in each variety tested. Monitored varieties established 6 homogeneous groups, which differed in content of lycopene (Table 2).

Statistically significant the lowest lycopene content was found in variety Nemarock. The highest content of carotenoids was statistically significant in San Marzano 4. Significant difference in the content of lycopene was not detected between varieties Strombolino and UG. 8168 .

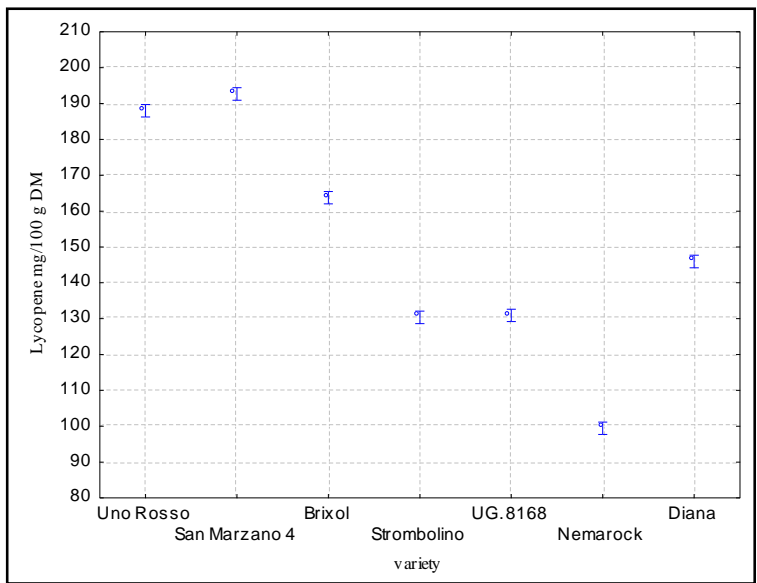

Figure 2 Comparison of averages of lycopene content (mg. $100 \mathrm{~g}$ ${ }^{1}$ dry matter) in the tomato fruit
The aim of this work was to evaluate the quality of selected tomato varieties intended for industrial processing. Fruit quality was assessed on the basis of technologically important properties such as dry matter content, organic acids and colorants. The dry matter content of the samples ranged from $4.65 \%$ to $5.93 \%$. The highest dry matter content was found in the variety San Marzano 4. Content of organic acids was the lowest in variety Nemarock $(0.33 \%)$ and highest in variety Strombolino. In terms of the content of colorants appeared to be the best variety San Marzano 4, in which was present $198.365 \mathrm{mg}^{100 \mathrm{~g}^{-1}}$ of total carotenoids, and lycopene has been accounted for $97.14 \%$ of that content. Higher content of carotenoids was observed also in varieties Uno Rosso and Brixol. In terms of treatment the best properties showed San Marzano 4, which is characterized by high content of dry matter, low organic acids and the high content of colorants.

Acknowledgments: The work was supported by ITMS 26220220180 project Building of Agrobiotech Research Centre.

\section{REFERENCES}

AGARW AL, A., RAO, A.V. 2000. Tomato lycopene and its role in human health and chronic diseases. Canadian Medical Association Journal, 2000, vol. 163, no. 6, p. 739-744. PMID: 11022591

AGARWAL, A., SHEN, H., AGARWAL, S., RAO, A. V. 2001. Lycopene content of tomato products: Its stability, bioavailability and in vivo antioxidant properties. Journal of Medicinal Food, 2001, vol. 17, no. 3, s. 9-15. ISSN 1557 7600

ANTHON, G. E., LE ST RANGEB, M., BARRETT A, D. M. 2011. Changes in $\mathrm{pH}$, acids, sugars and other quality parameters during extended vine holding of ripe processing tomatoes. Journal Science Food Agriculture, 2011, vol.91, no. 7 , p. 1175-81. PMID: 21384370 doi: 0.1002/jsfa.43122011.

BELITZ, H. D., GROSCH, W., SCHIEBERLE, P. 2009. Food chemistry. Berlin : Springer, 2009, 1070 p. ISBN 978-3-540- 69933-0

BORGUINI, R., TORRES, E. 2009. Tomatoes and tomato products as dietary sources of antioxidants. Food Reviews International, 2009, vol. 25, no. 4, p. 313 325. DOI: $\quad 10.1080 / 87559120903155859$

BUGIANESI, R., SALUCCI, M., LEONARDI, C., FERRACANE, R., CATAST, G., AZZINI, E., MAIANI, G. 2004. Effect of domestic cooking on human bioavailability of naringenin, chlorogenic acid, lycopene and beta-carotene in cherry tomatoes. European Journal of Nutrition, 2004, vol. 43, no. 6, p.360-366. PMID:15309458

CARLI, P., CARUSO, G., FOGLIANO, V., CARPUTO, D., FRUSCIANTE, L., ERCOLANO, M. R. 2011. Development of a methodology to forecast the nutritional value of new tomato hybrids. Euphytica, 2011, vol. 180, no. 3, p. 291 300. DOI 10.1007/s10681-011-0350-0

CLINTON, S. K. 1998. Lycopene; chemistry, biology and implications for human health and diseases. Nutrition Reviews, 1998, vol. 56, no. 2, p. 35-51 DOI: $10.1111 / \mathrm{j} .1753-4887.1998 . t b 01691 . x$

DORAIS, M., EHRET D., L.,PAPADOPOULOS, A. P. 2008. Tomato (Solanum lycopersicum) health components: from the seed to the consumer Phytochemistry Reviews, 2008, vol.7, no. 12, p. 231-250. ISSN 1568-7767 DOI 10.1007/s11101-007-9085-x

GARCÍA-VALVERDE, V., NAVARRO-GONZÁLES, I., GARCÍA-ALONSO, J., PERIAGO J. M. 2013. Antioxidant bioactive compounds in selected industrial processing and fresh consumption tomato cultivars. Food bioprocess technology, 2013, vol. 6, no. 12, p. 391-402. ISSN 1935-5149 DOI 10.1007/s11947-0110687-3

GIOVANNUCCI E., RIMM E., LIU Y., ST AMPFER M., WILLETTW. 2002. A prospective study of tomato products, lycopene, and prostate cancer risk. Journal of national cancer institute, 2002, vol. 94, no. 5, p. 391-398. ISSN 1460-2105 HERNÁNDEZ SUÁREZ, M., RODRÍGUEZ RODRÍGUEZ, E. M., DÍAZ ROMERO, C. 2008. Chemical composition of tomato (Lycopersicon esculentum) from Tenerife, the Canary Islands. Food Chemistry, 2008, vol. 106, no. 3, p 1046-1056. doi:10.1016/j.foodchem.2007.07.025

ILAHY, R., HDIDER, C., LENUCCI, M.S, TLILI, I., DALESSANDRO, G. 2011. Phytochemical composition and antioxidant activity of high-lycopene tomato (Solanum lycopersicum L.) cultivars grown in Southern Italy. Scientic Horticulturae, 2011, vol. 127 , no. 3, p. 255-261.

10.1016/j.scienta.2010.10.001

KHACHIK, F., CARVALHO, L., BERNSTEIN, P. S., MUIR, G. J., ZHAO, D. Y., KATZ, N. B. 2002. Chemistry, distribution, and metabolism of tomato carotenoids and their impact on human health. Experimental biology and medicine, 2002, vol. 99, no. 10, p. 845-851. ISSN 1535-3699

KOTÍKOVÁ, Z., HEJTMNKOVÁ, A., LACHMAN, J. 2009. Determination of the influence of variety and level of maturity of the content and development of carotenoids in tomatoes. Czech Journal Food Science, 2009, vol. 27, special issue, S200-S203. ISSN 1805-9317 
KOTÍKOVÁ, Z., LACHMAN, J., HEJTMÁNKOVÁ, A., HEJTMÁNKOVÁ, K. 2011. Determination of antioxidant activity and antioxidant content in tomato varieties and evaluation of mutual interactions between antioxidants. $L W T$ - Food Science \& Technology, 2011, vol. 44, no. 8, p. 1703-1710. DOI: 10.1016/j.lwt.2011.03.015

KUTI, J. O., KONURU, H. B. 2005. Effects of genotype and cultivation environment on lycopene content in red-ripe tomatoes. Journal of the science of food and Agriculture, 2005, vol. 85, no. 12, p. 2021-2026. DOI: 10.1002/jsfa.2205.

LENUCCI, M. S., CADINU, D., TAURINO, M., PIRO, G., DALESSANDRO, G. 2006. Antioxidant composition in cherry and high-pigment tomato cultivars Journal of A gricultural and Food Chemistry, 2006, vol. 54, no. 7, p. 2606-2613. DOI: $10.1021 /$ jf052920c

MAJIDI, H., MINAEI, S., ALMASI, M., MOSTOFI, Y. 2011. T otal Soluble Solids, Titratable Acidity and Repining Index of Tomato In Various Storage Conditions. Australian Journal of Basic and Applied Sciences, 2011, vol. 5, no.12, p. 1723-1726. ISSN 19918178

MART INEZ-VALVERDE, I.,PERIAGO, M. J., PROVAN, G., CHESSON, A. 2002. Phenolic compounds, lycopene and antioxidant activity in commercial varieties of tomato (Lycopersicum esculentum). Journal of agricult ural and food chemistry, 2002, vol. 82, no. 3, p. 323-330. DOI: 10.1002/jsfa.1035. MOCO, S., BINO, R. J., VORST, O., VERHOEVEN, H. A., DE GROOT, J., VAN BEEK, T. A., VERVOORT, J., DE VOS, J. H. R. 2006. A liquid chromatography-mass spectrometry based metabolome database for tomato. Plan Physiology, 2006, vol. 141, no. 4, p. 1205-1218. doi: http://dx.doi.org/10.1104/pp.106.078428

MUlLER, K., CARPENTER, K. L., CHALLIS, I. R., SKEPPER, J. N. ARENDS, M. J. 2002. Carotenoids induce apoptosis in the T-lymphoblast cell line Jurkat E6.1. Free Radical Research, vol.36, no. 7, p. 791-802. ISSN 08915849

POHAR, K. S., GONG, M.C., BAHNSON, R., MILlER, E. C., CLINTON S. K. 2003. Tomatoes, lycopene and prostate cancer: a clinician's gurde for counseling those at risk for prostate cancer. World Journal of Urology, 2003, vol. 21, no. 1. p. 9-14. ISSN 0724-4983
RAJORIA, A., KUMAR, J., CHAUHAN, A. K. 2010. Antioxidative and anticarcinogenic role of lycopene in human health. Journal of dairying, foods and home sciences, vol. 29, no. 3, p. 157-165. ISSN 978-1-85573-394-7

SHARMA, S. K., LE MAGUER, M. 1996. Lycopene in tomatoes and tomato pulp fractions. Italian Journal of Food Science, 1996. vol. 8, no. 2, p. 107-113. ISSN 11201770

TOOR, R. K., SAVAGE, G. P., LISTER, C. E. 2006. Seasonal variations in the antioxidant composition of greenhouse-grown tomatoes. Journal of food composition and analysis, 2006, vol. 19, no. 1, p. 1-10. http://dx.doi.org/10.1016/j.jfca.2004.11.008.

SESSO, H. D., BURING, J. E., NORKUS, E. P., GAZIANO, J. M. 2004. Plasma lycopene, other carotenoids, and retinol and the risk of cardiovascular disease in women. The American Journal of Clinical Nutrition, 2004, vol. 79, no. 1, p. 4753. ISSN 1938- 3207

SESSO, H. D., LIU, S., GAZIANO, J. M., BURING, J. E. 2003. Dietary lycopene, tomato-based food products and cardiovascular disease in women. Journal of Nutrition, vol. 133, no. 7, p. 2336-2341. ISSN 1541- 6100

SRIVAST AVA, S., SRIVAST AVA, A. K. 2012. Lycopene; chemistry, biosynthesis, metabolism and degradation under various abiotic parameters Journal of Food Science and Technology, 2012, vol. 49, no. 1, ISSN 0022-1155 DOI 10.1007/s13197-012-0918-2.

ST AHL, W., SIES, H. 2005. Bioactivity and protective effects of natural carotenoids. Acta Biochimica et Biophysica, 1740, no. 2, p. 101-107. ISSN 0006-3002. DOI: 10.1016/j.bbadis.2004.12.006

VALLVERDÚ-QUERALT, A., MEDINA-REMÓN, A., MARTÍNEZHUÉLAMO, M., JÁUREGUI O., ANDRES-LACUEVA, C., LAMUELARAVENTOS, R. M. 2011. Phenolic profile and hydrophilic antioxidant capacity as chemotaxonomic markers of tomato varieties. Journal of Agricultural and Food Chemistry, 2011, vol. 59, no. 9, p. 3994-4001. DOI: 10.1021/jf104400g WALIA, S., SINGH, M., KAUR, CH., KUMAR, R., JOSHI, S. 2010. Antioxidant Composition of Red and Orange Cultivars of Tomatoes (Solanum lycopersicon L): A Comparative Evaluation. Journal Plant Biochemistry \& Biotechnology, 2010, vol. 19, no. 1, p. 95-97. ISSN 0974-1275

ZEB, A., MEHMOOD, S., 2004. Carotenoids contents from various sources and their potential health applications. Pakistan Journal of Nutrition, 2004, vol. 3, no. 3, p. 199-204. 